\title{
Sanna Katariina Bruun
}

\section{Valheen jäljet: Fiktion ja ei-fiktion kysymyksiä Emmanuel Carrèren teoksessa Valhe}

"Ajattelin, että tämän tarinan kirjoittaminen voisi olla vain joko rikos tai rukous." (Valhe, 155.)

Emmanuel Carrèren teos Valhe (L'Adversaire, 2000) kertoo ranskalaisesta miehestä Jean-Claude Romandista, joka vuonna 1993 tappoi vaimonsa, kaksi lastaan sekä omat vanhempansa. Hän yritti tappaa myös itsensä, mutta jäi henkiin. Seuranneen rikostutkinnan myötä paljastui, että koko Romandin elämä oli ollut käsittämätöntä valhetta. Romand esiintyi kahdeksantoista vuoden ajan menestyvänä lääkärinä vaikka oli tosiasiassa ammattitaidoton, työtön ja vailla tuloja. Kukaan Romandin lähimmäisistä ei tiennyt totuutta, ei edes hänen vaimonsa. Vuosien kuluessa valheet kasvoivat kasvamistaan, ja lopulta Romand päätyi tappamaan läheisensä ajatellen sen olevan parempi ratkaisu kuin totuuden paljastuminen. Kyseessä on tositapaus, joka herätti aikanaan suurta huomiota ranskalaisessa mediassa ja jota erityisesti lehdistö kierrätti yhä uudelleen aina Romandin oikeudenkäyntiin ja tuomioon asti. Ennen teoksen kirjoittamista Carrère ryhtyi kirjeenvaihtoon Romandin kanssa, osallistui journalistina tämän oikeudenkäyntiin ja myös kirjoitti tapauksesta artikkelisarjan ranskalaiseen aikakausilehteen.

Valhe ei kuitenkaan ole Romandin elämäkerta tai selkeästi faktuaalinen selonteko tapahtumista, mitä tähdentää sekin, että Romandin tarinaa kehystää kuvaus itse teoksen kirjoitusprosessista. Valheen kertoja osoittaa eksplisiittisesti olevansa yhtä kuin kirjailija Carrère sekä nimeämällä itsensä että viittaamalla tarkistettavissa oleviin elämäkertatietoihin. Kirjailija-kertoja kertoo itsestään, päätöksestään kirjoittaa tapauksesta sekä kirjoittamisen viivästymisestä ja vaikeudesta. Valhe pohtii siis myös sitä, miten tämänkaltaisiin täysin uskomattomalta tuntuviin tosielämän tapahtumiin voi tai pitäisi suhtautua ja miten niistä voi tai pitäisi kirjoittaa. Teos operoi ei-fiktion ja fiktion välimaastossa: se ei ole fiktiivinen, mutta ei myöskään selkeästi ei-fiktiivinen. Teoksesta itsestään nousevat esiin kysymykset faktan ja fiktion välisestä suhteesta sekä todellisuuden representaatiosta, jotka tematisoituvat niin aiheen kuin kerronnankin tasolla. Tuomalla näkyviin oman kirjoitusprosessinsa, reflektoimalla sen ongelmia ja kyseenalaistamalla samalla todellisten tapahtumien objektiivisen representaation mahdollisuuden Valhe tuntuu tietoisesti pyrkivän hämärtämään fiktiivisten ja ei-fiktiivisten tekstien välistä rajaa.

Kirjailija-kertoja nostaa heti teoksen alkupuolella esiin myös kysymyksen teoksen kirjoittamisen motiiveista. Hän arvelee, että perinteinen journalistisen lähestymistapa, 
pyrkimys tuoda esiin tapahtuneet tosiseikat pienimpiä yksityiskohtia myöten, ei olisi tavoittanut sitä, mitä hän todella halusi saada selville:

[--] kaikki se minkä saisin aikanaan tietää, ei kertoisi sitä mitä minä todella halusin tietää. Halusin tietää mitä Romandin päässä liikkui [--] Kysymykseen, joka sai minut kokeilemaan kirjan kirjoittamista, eivät todistajat, tutkintotuomari eivätkä psykiatriset asiantuntijat voisi vastata. Siihen pystyisi vastaamaan vain joko Romand itse, koska hän oli hengissä, tai sitten ei kukaan. (Valhe, 22-23.)

Jo teoksen kirjoittamisen lähtökohdissa kiteytyy kysymys fiktiivisten ja ei-fiktiivisten tekstien eroista, samankaltaisuuksista ja - mikä olennaisinta - niiden kuvausvoimasta. Kirjailija-kertoja päätteleekin, että tapahtumien objektiivinen esittäminen on mahdotonta, ja löytää lopulta oman näkökulmansa tarinaan tematisoimalla Romandin tarinan keskeiseksi kysymykseksi todellisten tapahtumien kuvaamisen vaikeuden. Kirjailijakertojan subjektiivinen näkökulma tulee esiin niin tapauksen avoimessa kommentoinnissa kuin sen tulkinnassakin. Vertaamalla Romandin elämää omaansa, pohtimalla omia tunteitaan ja reaktioitaan sekä yrittämällä ymmärtää, mitä Romandin päässä liikkui, kirjailija-kertoja pyrkii löytämään tavan, jolla tapauksesta olisi mahdollista kertoa. Samalla kirjailija-kertojan esittämät kysymykset ja hänen subjektiivinen näkökulmansa kurkottavat tekstistä lukijan omaan todellisuuteen ja vaativat lukijaa muodostamaan oman suhteensa epätodellisilta tuntuviin tapahtumiin. Valhe haastaa lukijan mukaan niin toden ja valheen, faktan ja fiktion kuin ei-fiktiivisten ja fiktiivisten tekstien välisten rajojen määrittelyyn.

Tarkastelen artikkelissani Carrèren teosta juuri niiden faktan ja fiktion sekä todellisuuden representaation kysymysten kautta, joita teos itse nostaa esiin. Tällainen rajankäynti liittyy edelleen hyvin laajoihin teoreettisiin kysymyksiin fiktion ja ei-fiktion käsitteiden määrittelystä ja niiden välisestä suhteesta ${ }^{1}$, mutta artikkelini puitteissa tähän laajempaan teorianmuodostukseen ei kuitenkaan ole mahdollista tarkemmin puuttua. Tarkoitukseni on havainnollistaa yhden sangen poikkeuksellisen teoksen suhdetta fiktioon ja ei-fiktioon keskittymällä erityisesti siihen, miten Valheen kerronnan ja rakenteen analyysi voi auttaa avaamaan ja märitttelemään teosta.

\section{Epätodellisen todellisuuden jalanjäljillä}

Päätettyään kirjoittaa Romandin tapauksesta Carrère lähetti Romandille kirjeen, jossa hän tiedusteli tämän mielipidettä hankkeesta (kirje on painettu kokonaisuudessaan osaksi teosta). Kirjailija-kertoja kuvaa, kuinka hän kirjeen postittamisen jälkeen mietti vaihtoehtojaan siinä tapauksessa, että Romand ei vastaisi hänelle:

Mietin: jos Romand jostain kumman syystä suostuu puhumaan kanssani [--] työni johtaa minut täysin tuntemattomille vesille. Ellei Romand vastaa minulle, mikä on todennäköisempää, kirjoitan tapauksen "innoittamana" 
romaanin, vaihdan nimet, tapahtumapaikat ja olosuhteet, keksin omasta päästäni: teen fiktiota. (Valhe, 25.)

Kirjailija-kertoja toteaa, että Romandin vastauksen viipyessä hän todella päätyi kirjoittamaan fiktiivisen tarinan murhaaja-isästä, mutta tarinaa ei koskaan julkaistu. Muutamaa vuotta myöhemmin Romand kuitenkin vastasi Carrèren kirjeeseen, ja teos Valhe on todennäköisesti seuraus tästä kirjeestä, joka johdatti Carrèren "tuntemattomille vesille". Kirjailija-kertojan julkaisematonta romaania ja Romandin henkilökohtaista merkitystä koskevista kommenteista on luettavissa, että käsillä oleva teksti olisi jotakin muuta kuin fiktiota. Tästä huolimatta teos ei selkeästi pyri osoittamaan olevansa ei-fiktiivinen. Romandin tapauksen lisäksi kirjailija-kertoja kuvailee paitsi teoksen kirjoitusprosessia myös omia tunteitaan, tulkintojaan ja käsityksiään tapauksesta. Monet Romandin lapsuutta tai elämää ennen valheiden paljastumista kuvaavat jaksot on kerrottu varsin vapaasti selvittämättä, mistä tiedot näistä elämänvaiheista ovat peräisin. Lukijan on usein vaikea erottaa, onko kyseessä tapauksen dokumentointi vai kirjailijakertojan sepite. Teoksen fiktiivisen tai ei-fiktiivisen statuksen epäselvyys virittää kysymään, miten Valhe lopulta eroaa kirjailija-kertojan oletettavasti kirjoittamasta fiktiivisestä tarinasta, ja myös, olisiko ero ollut selkeämpi, jos teos olisi selvemmin pyrkinyt faktuaaliseen selontekoon.

Valhe ei esitä eksplisiittistä totuusväittämää. Huolimatta siitä, että teoksen kertoja voidaan samastaa kirjailija Carrèreen ja että lukija voi kirjailija-kertojan antamien tietojen perusteella tarkistaa kuvattujen tapahtumien todenperäisyyden, ei teos anna selkeää merkkiä omasta faktuaalisuudestaan. Yhtä merkittävää on se, ettei teos esitä olevansa myöskään fiktiivinen, vaan kirjailija-kertojan voidaan pikemminkin nähdä asettavan parhaillaan kirjoittamansa teos vastakkain aiemmin kirjoittamansa fiktiivisen version kanssa. Samoin myös kirjailija-kertojan tarve saada Romandilta itseltään vastaus häntä askarruttaviin kysymyksiin viittaa siihen, ettei hän tyydy vain sepittämään vastauksia, vaan haluaa jollakin tavoin saada selville, mitä 'todella tapahtui'. Totuusväittämän sijaan Valhe tuntuukin samaan aikaan sekä kyseenalaistavan todellisuuden kuvaamisen mahdollisuuden että korostavan todellisten tapahtumien merkitystä tekstille ja näin ollen nostavan tietoisesti esiin kysymyksen fiktion ja ei-fiktion välisistä rajoista.

Kirjailija-kertojan itserefleksiivinen kirjoitusprosessin tarkastelu ei selvennä saati ratkaise kysymystä teoksen fiktiivisyydestä tai ei-fiktiivisyydestä, vaan ennemminkin korostaa sen ongelmallisuutta ja tapahtumien objektiivisen esittämisen mahdottomuutta. Seuraava katkelma on Carrèren Romandille lähettämästä kirjeestä, jossa hän kertoo keskeyttäneensä teoksen kirjoittamisen toistaiseksi sen mukanaan tuomien ongelmien vuoksi:

Ongelmani ei ole, kuten ensin luulin, tiedon puute, vaan se miten löytäisin oman näkökulmani teidän tarinaanne. Työhön ryhtyessäni uskoin voivani 
sivuuttaa tämän ongelman ompelemalla yhteen kaikki tietämäni langan päät ja pyrkimällä olemaan objektiivinen. Mutta objektiivisuus on tällaisessa tapauksessa petosta. Minun täytyi valita näkökulma². (Valhe, 144.)

Lisäksi on huomattava, että todellisuuden kuvaaminen ei problematisoidu vain kirjailija-kertojan kerronnan vaan myös itse aiheen tasolla. Kuvauksen kohteena olevat tapahtumat tuntuvat jo sinällään täysin epätodellisilta. Kyse on käsittämättömät mittakaavat saaneesta tapauksesta, jossa itsessään sekoittuvat toden ja epätoden rajat. Valhe pyrkii kuvaamaan miestä, jonka todellinen elämä ja identiteetti ovat olleet valhetta ja jonka ylläpitämän kulissin takana tuntuu olevan pelkkää tyhjä. Kysymys ei siis ole vain todellisten tapahtumien ja teoksen kerronnan suhteesta, vaan myös kuvatun henkilön ja todellisuuden suhteesta. Teos ei kysy vain sitä, miten voidaan kertoa todellisista tapahtumista, vaan myös sitä, miten voidaan kertoa todellisesta ihmisestä, jonka oma todellisuus on täysin epätodellinen.

Valheen kerronnan itserefleksiivisyys, fiktion ja ei-fiktion välisen rajan kyseenalaistaminen sekä pyrkimys löytää tapa, jolla kuvata epätodellisilta tuntuvia todellisuuden tapahtumia, tuovat monella tavoin mieleen ei-fiktiiviseen romaaniin liittyvän problematiikan. Ei-fiktiivinen romaani on alun perin uudissana, jonka Truman Capote lanseerasi asemoidakseen teostaan Kylmäverisesti (In Cold Blood, 1965). Termi on kiistellyistä lähtökohdistaan huolimatta jäänyt käyttöön tietynlaisten, fiktion keinoja hyödyntävien faktuaalisten tekstien kuvaajana. Ei-fiktiivisen romaanin käsitettä voidaan tietysti pitää jo itsessään ongelmallisena sanan "romaani” herättämien fiktiivisten konnotaatioiden vuoksi, ja niin käsitteen merkityksestä kuin käyttökelpoisuudestakin on kiistelty paljon. Valheen analyysin kannalta ei kuitenkaan ole tässä yhteydessä mielekästä heittäytyä ei-fiktiivisen romaanin tai laajemmin kaunokirjallisen ei-fiktion yksityiskohtaiseen tarkasteluun; olennaisempaa on huomioida, mitä yhtäläisyyksiä ja eroja on löydettävissä Carrèren teoksen ja ei-fiktiiviseen romaaniin tyypillisesti liitettyjen piirteiden välillä. ${ }^{3}$ Yksi näkyvimmistä yhtäläisyyksistä on Valheen kerronnan itserefleksiivisyys ja erityisesti teoksen kirjoitusprosessin reflektointi. Itserefleksiivisyys vaikuttaisi olevan yksi keskeisimmistä kaunokirjallista ei-fiktiota määrittelevistä piirteistä, vaikka onkin huomattava, etteivät kaikki tähän genreen liitetyt tekstit ole yhtälailla itsensätiedostavia tai kriittisesti refleksiivisiä. Itserefleksiivisyyden merkitystä kaunokirjalliselle ei-fiktiolle tai suppeammin ei-fiktiiviselle romaanille havainnollistaa hyvin polemiikki, jonka Capoten Kylmäverisesti ja hänen teoksen faktuaalisuudesta esittämänsä lausunnot nostattivat. Capoten väitteisiin varauksella suhtautuvien kriitikoiden ja tutkijoiden keskeisimpiä argumentteja oli juuri itserefleksiivisyyden ja erityisesti teoksen kirjoitusprosessia koskevan reflektoinnin puuttuminen. Esimerkiksi Phyllis Frus toteaa käsitellessään rinnan Capoten teosta ja Norman Mailerin Pyövelin laulua (The Executioner's Song, 1979), että Maileriin verrattuna Capoten tekstistä puuttuu olennaisella tavalla tietoisuus omasta kirjoitusprosessista (Frus 1994, 182-183). 
Toinen piirre, joka yhdistää Valheen ei-fiktiivisen romaanin kysymyksiin, on käsitys kuvattaviin tapahtumiin liittyvästä epätodellisuuden tunnusta ja perinteisempien fiktiivisten tai ei-fiktiivisten tekstilajien kyvyttömyydestä kuvata tämänkaltaisia tapahtumia. Kuten Frus osuvasti toteaa, todellisuuden epätodellisuudesta tai absurdiudesta on muodostunut yleisesti hyväksytty selitys kaunokirjallisen realismin hylkäämiselle ja siirtymävaiheelle kohti joko dokumentaarisia tai fabulistisia kirjoittamisen muotoja (Frus 1994, 162). Ajatus todellisuuden muuttumisesta epätodelliseksi vahvistui Yhdysvalloissa 1960-luvulla, jolloin amerikkalaisen todellisuuden ja kulttuurin koettiin Kennedyn murhan, massamedian synnyn ja Vietnamin sodan myötä muuttuneen perinpohjaisesti (ks. mm. Hellmann 1981, 2). John Hellmann toteaa, että uuden epävakaan ja oudon todellisuuden edessä amerikkalaiset kirjailijat hylkäsivät realismin ja ryhtyivät kirjoittamaan Kurt Vonnegutin ja John Barthin tavoin todellisuudesta irrallaan olevia tarinoita tai kääntyivät Capoten ja Mailerin lailla kohti faktuaalista mutta luovaa kerrontaa (Hellmann 1981, 10). Mas'ud Zavarzadeh puolestaan esittää, että todellisuuden kriisitilanteet tai poikkeukselliset tapahtumat vaativat uusia realismin rajat ylittäviä kerronnallisia keinoja, ja Zavarzadehille tämänkaltaisten keinojen ilmentymä on juuri ei-fiktiivinen romaani (Zavarzadeh 1976, 94). Vaikka Hellmannin ja Zavarzadehin kuvaileman uudenlaisen absurdin todellisuuden juuret ovatkin selkeästi amerikkalaisessa kulttuurissa, tuntuu käsitys todellisuuden epätodellisuudesta muutamassa vuosikymmenessä muuttuneen globaaliksi. Siitä on tullut eräänlainen selviö paitsi tietyntyyppisten kaunokirjallisten suuntausten selittäjänä myös laajemmassa kulttuurisessa mielessä.

Käsitellessään ajatusta absurdista todellisuudesta Frus nostaa esiin tärkeän kysymyksen siitä, mikä maailmastamme tekee nykyisin niin epäuskottavan. Vaikka 1900-luku pitääkin sisällään monia ennennäkemättömiä katastrofeja, lienee todennäköistä, että sodat, nälänhädät ja epidemiat ja muut suuret onnettomuudet ovat aina vaikuttaneet niihin osalliseksi joutuneista ihmisistä epätodellisilta ja absurdeilta. Frus esittääkin, että kysymyksessä ei ole niinkään todellisuudessa tai edes sen yksilöllisessä kokemisessa tapahtunut muutos, vaan pikemminkin erilaisten tekstuaalisten muotojen (kuten sanomalehtien, radion, television ja elokuvan) välittämä illuusio todellisuudesta on muuttunut epätodellisen ja absurdin tuntuiseksi. Samalla median kuvaama todellisuus ja sen käyttämä kuvaamisen tapa ovat kietoutuneet toisiinsa niin, että median luomasta maailmankuvasta on tullut yksilöllisiä kokemuksiamme "objektiivisempi”. Frus ehdottaa, että ajatus käsityskykymme ja tekstien kuvausvoiman ylittävästä todellisuudesta perustuukin kenties pelkoon tekstien voimasta, sillä juuri tekstit ovat muuttaneet todellisuuttamme tai käsitystämme siitä enemmän kuin mikään muu. (Frus 1994, 162-166.) Valheen kohdalla lukijan on kuitenkin vaikea olla kysymättä, eikö Romandin tapauksessa itsessään, representaation tavasta tai muodosta riippumatta, ole jotakin epätodellista ellei peräti absurdia. Romand ei toki ole ensimmäinen valheellisen identiteetin itselleen luonut ja epätoivoiseen tekoon päätynyt yksilö ihmiskunnan historiassa, mutta hänen 
tapauksestaan tekee poikkeuksellisen kaksi seikkaa: ensiksikin hämmästyttää se, että näin suuren mittakaavan petos oli mahdollista modernissa tietoyhteiskunnassa. On myös erikoista, että Romandin valheellisen identiteetin taakse ei kätkeytynyt toista identiteettiä tai toista elämää. Juuri nämä kysymykset tuntuvat vaivaavan eniten myös Valheen kirjailija-kertojaa:

Muutama puhelinsoitto tulipalon jälkeisenä päivänä riitti romahduttamaan tämän julkisivun. [--] On mahdotonta ajatella tätä tarinaa miettimättä, että juuri siinä piilee arvoitus ja kätketty selitys. Mutta arvoitus on se, että selitystä ei ole, ja että niin epäuskottavalta kuin se tuntuukin, asiat sujuivat näin.

(Valhe, 65.)

Valheen tehtävä on yleensä kätkeä totuus - jotakin, joka on ehkä häpeällistä mutta todellista. Hänen valheensa ei kätkenyt mitään. Valelääkäri Romandin alla ei ollut mitään todellista Jean-Claude Romandia. (Valhe, 69.)

Miettiessään, miten kertoa epätodellisen ja jopa absurdin tuntuisesta todellisuudesta, Valheen kirjailija-kertoja ratkaisee lopulta ongelman valitsemalla hyvin henkilökohtaisen ja subjektiivisen näkökulman suhteessa Romandiin ja kuvattuihin tapahtumiin. Valhe alkaa kirjailija-kertojan toteamuksella siitä, missä hän itse oli Romandin tappaessa perheensä, ja kirjailija-kertoja myös vertaa toistuvasti oman elämänsä tapahtumia ja yksityiskohtia Romandin elämän tapahtumiin - joskus jopa naiiviuteen asti. Subjektiivinen näkökulma myös yhdistää toisiinsa piirteet, jotka liittävät teoksen kaunokirjallisen ei-fiktion tai ei-fiktiivisen romaanin kysymyksiin. Epätodellisen tuntuinen todellisuus johtaa henkilökohtaisen näkökulman valintaan, joka puolestaan johtaa itserefleksiivisyyteen. Markku Lehtimäki toteaa itserefleksiivisen ei-fiktion vaativan myös lukijaltaan refleksiivisyyttä ja viittaa Susana Onegan ja José Angel García Landan esittämään näkemykseen, jonka mukaan refleksiivisyyden käsite kiinnittää huomion niin tekstien erilaisiin peilirakenteisiin kuin ajatteluun, tajuntaan, reflektioon ja tietoisuuteen rinnakkaisesta toiminnasta (Lehtimäki 2005, 11). Valheessa kirjailija-kertoja pyrkii ankkuroimaan Romandin elämän epätodentuntuiset tapahtumat todellisuuteen käyttämällä omaa elämäänsä Romandin tarinan peilirakenteena. Kirjailija-kertoja yrittää ymmärtää Romandin tajuntaa ja toimintaa vertaamalla niitä siihen, miten hän itse ajattelee ja toimii tai olisi kenties ajatellut ja toiminut vastaavissa tilanteissa. Subjektiivisen näkökulman kautta kirjailija-kertojasta siis muodostuu tietyllä tapaa myös Romandin tarinan lukija, jonka itsereflektio vaatii myös teoksen lukijalta refleksiivisyyttä.

Tässä kohden Valhe tuntuu myös eroavan esimerkiksi Capoten ja Mailerin edellä mainituista teoksista. Chris Anderson esittää, että Capoten Kylmäverisesti-teoksen lukukokemus perustuu ennen kaikkea tekijän äänettömyyteen (authorial silence), sillä tekijän hiljaisuudesta johtuvien informatiivisten ja tulkinnallisten aukkojen vuoksi lukijan on osallistuttava merkitysten luomiseen (Anderson 1987, 48-49). Lehtimäki puolestaan toteaa samanlaisen äänettömyyden tai hiljaisuuden retoriikan luonnehtivan 
myös Mailerin Pyövelin laulua, vaikka huomauttaakin Mailerin hyödyntävän lukijan osallistumista vaativaa hiljaisuutta, monimerkityksisyyttä ja aukkoisuutta paljon Capotea voimallisemmin (Lehtimäki 2005, 300-301). Valheen kirjailija-kertoja sen sijaan on kaikkea muuta kuin äänetön. Törmätessään informaation puutteeseen, tulkinnan hankaluuteen tai kuvauksen mahdottomuuteen kirjailija-kertoja täyttää syntyvän aukon itsellään: oman elämänsä ja kirjoitusprosessin reflektoinnilla tai tapahtumien avoimen subjektiivisella tulkinnalla. Mielenkiintoista kyllä Valheen kirjailija-kertojan subjektiivisen retoriikan vaikutus on pitkälti samankaltainen kuin Capoten tai Mailerin hiljaisuuden. Kirjailija-kertojan näkökulma on liian henkilökohtainen ja itserefleksiivinen tarjotakseen lukijalle helppoa samaistumiskohdetta. Teos ei niinkään kutsu lukijaa jakamaan kirjailija-kertojan näkökulmaa, vaan pikemminkin vaatii lukijaa osallistumaan merkitysten muodostamiseen ja valitsemaan oma näkökulmansa suhteessa kuvattuihin tapahtumiin.

\section{Valheiden poetiikkaa}

Yksi keskeisimpiä tosielämän rikoksia kuvaavia ja tietyssä märin kaikkia ei-fiktiivisiä teoksia koskeva kysymys on se, kenen tarinasta niissä viime kädessä on kyse. Esimerkiksi Kylmäverisesti-teoksen ja Pyövelin laulun kohdalla kysymys on esillä jo teosten nimissä (ks. Lehtimäki 2005, 68). Teokset eivät kerro vain järjettömiltä tuntuvista murhista, vaan kyseessä on yhtä lailla myös noiden murhien tekijöiden ja heidän kohtalonsa tarina. Murhaajan tarinan kertominen puolestaan virittää kysymyksen ei-fiktiivisen (ja myös fiktiivisen) kirjoittamisen etiikasta. Capoten sympatia murhaaja Perry Smithia kohtaan on noussut keskeiseksi aiheeksi Kylmäverisesti-teoksen ei-fiktiivisyyttä koskevassa kritiikissä. Mailerin Pyövelin laulun vahvuutena on puolestaan nähty se, että teos kiinnittää huomiota tapahtumien ja Gary Gilmoren persoonan kuvaamisen eettiseen ongelmallisuuteen, samoin kuin se, että kirjailijan/kertojan oma asenne tuomittua murhaajaa kohtaan on varsin moniselitteinen (ks. Lehtimäki 2005, 69, 310-311). Valheen kirjailija-kertoja on hyvin tietoinen murhaajan tarinan kertomiseen liittyvästä eettisestä ja moraalisesta vastuusta. Esimerkiksi seuratessaan Romandin oikeudenkäyntiä kirjailijakertoja toteaa olevansa kyvytön kohtaamaan Romandin anoppia, sillä:

Minä en ollut kirjoittanut hänelle enkä hänen omaisilleen, vaan ihmiselle, joka oli tuhonnut heidän elämänsä. Olin sitä mieltä että minun piti kiinnittää huomioni juuri tähän ihmiseen, koska tarina jonka halusin kertoa oli minusta nimenomaan bänen tarinansa. (Valhe, 34.)

Kirjailija-kertoja ei kuitenkaan tunne eettistä ja moraalista vastuuta vain suhteessa tapauksen uhreihin tai heidän omaisiinsa, vaan myös suhteessa Romandiin ja tämän esittämiin odotuksiin: 
Ymmärsin hänen uskovan, että minulla olisi paremmat mahdollisuudet kuin psykiatreilla saada hänet ymmärtämään omaa elämäänsä ja että minä pystyisin asianajajia paremmin saamaan muut ihmiset ymmärtämään sitä. Näin suuri vastuu hirvitti minua, mutta eihän hän ollut tullut minun luokseni, vaan ensimmäisen askeleen olin ottanut minä, joten minun oli myös hyväksyttävä seuraukset. (Valhe, 29.)

Kirjailija-kertojan kuvaamat vastuun ja jopa syyllisyyden tunteet tuovat mieleen Daniel W. Lehmanin esittämän ajatuksen ei-fiktiivistä (ja tietyssä määrin myös fiktiivistä) kirjoittamista varjostavasta syyllisyyden tunteesta (Lehman 1997, 32-34). Reflektoimalla toistuvasti omia motiivejaan sekä itseään, Romandia, tapauksen uhreja ja jopa omaa poikaansa kohtaan tuntemaansa syyllisyyttä kirjailija-kertoja luo vaikutelman, että hän todella pyrkii kantamaan hankkimansa vastuun seuraukset. On kuitenkin huomattava, että kysymys ei-fiktiivisen kirjoittamisen eettisyydestä ei liity vain itserefleksiivisyyteen tai siihen, kenen tarinan teos lopulta kertoo, vaan yhtä lailla myös kysymykseen kerronnan tavasta ja käytetyistä kerrontatekniikoista. Lähestyttäessä ei-fiktiivisten tekstien kerrontateknisiä kysymyksiä eettisestä näkökulmasta yhdeksi keskeisimmistä ongelmista nousee henkilöhahmojen sisäisen tajunnan kuvaus, jota pidetään nimenomaan yhtenä fiktiivisen kerronnan ominaispiirteenä (Cohn 2006, 139-140). Näkemystä sisäisen tajunnan kuvauksesta tekstin fiktiivisyyden merkkinä perustelee paitsi se tosiseikka, että todelliset ihmiset eivät pysty lukemaan toistensa ajatuksia, myös kysymys toisen ihmisen sisäisten mielenliikkeiden kuvauksen eettisyydestä. Fiktiivisten henkilöhahmojen yksityisyyttä ei voida loukata yhtä helposti kuin todellisten ihmisten. Myös Lehmanille yhdeksi keskeisimmäksi fiktiota ja ei-fiktiota erottavaksi tekijäksi nousee henkilöhahmojen ajatusten tai toimintojen kuvaus. Fiktion kirjoittajalla on valta tavoittaa ja kuvata mikä tahansa ajatus tai tapahtuma, mutta ei-fiktiossa kyky lukea henkilöhahmojen ajatuksia tai kuvata tapahtumia, joissa itse ei ole ollut läsnä, ei koskaan ole täysin "viatonta”. (Lehman 1997, 35, 48.)

Valheen kerronta on edellä mainitusta näkökulmasta katsottuna ongelmallista. Vaikka kirjailija-kertoja reflektoi toistuvasti kirjoittamiseen liittyviä teknisiä ja moraalisia ongelmia ja tuntuu korostavan kirjoittamansa tekstin ja aiemman fiktiivisen version välistä eroa, hyödyntää hän samalla myös monia fiktion kirjoittajan 'vapauksia' ilman mainittavaa itsereflektiota. Yksi pulmallisimmista kohdista on heti teoksen alkuun sijoittuva jakso, jossa murhia seurannutta tulipaloa ja seuraavina päivinä tapahtunutta tapauksen selvittelyä kuvataan Romandin hyvän ystävän Lucin näkökulmasta. Kertojana on koko kyseisen jakson ajan ulkopuolinen kolmannen persoonan kertoja, joka kuvaa toistuvasti ja ilman rajoituksia henkilöhahmojen sisäisiä mielenliikkeitä käyttäen usein vapaata epäsuoraa esitystä:

Juttu oli vaivannut häntä, ja hän ja Cécile olivat puineet sitä monena iltana peräjälkeen. Kuinka naurettavalta se nyt tuntuikaan! Kuinka hauras elämä olikaan! (Valhe, 9.) 
Kunpa he olisivat voineet edes suojella lapsiaan! Oli hirveää kertoa jo se, että Antoine ja Caroline olivat menehtyneet tulipalossa vanhempiensa kanssa.

Mutta hyssyttely oli turhaa. (Valhe, 12.)

Lukuun ottamatta teoksen ensimmäiselle sivulle irralleen sijoitettua kirjailija-kertojan vähäeleistä lausuntoa siitä, missä hän itse oli Romandin tappaessa perheensä, ei Valheen alun kerronta vaikuta pyrkivän ei-fiktiivisyyteen. Mikäli henkilöhahmojen sisäisen tajunnan kuvausta pidettäisiin selkeänä merkkinä tekstin fiktiivisyydestä, olisi lukijan tässä kohden suhtauduttava teokseen fiktiona. Edellä mainitun jakson jälkeen muuttuu kerronta yhtäkkiä kirjailija-kertojan minäkerronnaksi, mutta teoksen alulle ei tarjota minkäänlaista selitystä. Kirjailija-kertoja viittaa kyseiseen jaksoon vasta teoksen loppupuolella kirjeessään Romandille tarjoten jaksolle samalla jonkinlaisen selityksen:

Lähdin tapaamaan ystäväänne Lucia ja pyysin häntä kertomaan, millaista hänen ja hänen omaistensa elämä murhenäytelmän paljastumisen jälkeen oli. Yritin kirjoittaa siitä samaistumalla häneen enkä juuri tuntenut tunnonvaivoja, koska hän oli sanonut minulle, ettei halunnut esiintyä kirjassa omalla nimellään. Kohta tulin kuitenkin siihen tulokseen, etten voinut (en teknisesti enkä moraalisesti, molemmat kulkevat käsi kädessä) pitäytyä tässä näkökulmassa. (Valhe, 144.)

Kirjailija-kertoja osoittaa siis olevansa tietoinen siitä, että kerronnan tapa tai tekniikka ja kysymykset todellisten tapahtumien kuvaamisen eettisyydestä kulkevat käsi kädessä. On kuitenkin mielenkiintoista - teknisesti ja moraalisesti - että teoksen aloittaa jakso, jonka näkökulman kirjailija-kertoja itse myöhemmin toteaa olevan ongelmallinen ja joka on omiaan herättämään lukijassa kysymyksen siitä, onko kyseessä tapauksen dokumentointi vai sepite.

Dorrit Cohn toteaa, että myös historiankirjoittajat ja erityisesti elämäkertakirjoittajat kuvaavat henkilöhahmojen mielenliikkeitä, mutta historiankirjoituksen ja fiktion ero perustuu tässä kohden hienovaraisiin teknisiin seikkoihin. Elämäkertakirjoittaja osoittaa mielenliikkeiden kuvauksen pohjautuvan arvailuun tai päättelyyn käyttämällä konditionaalimuotoa tai ehdollisia ilmauksia, kuten "ehkä" tai "varmaankin" (Cohn 2006, 38-39.) Kirjailija-kertoja käyttää Romandin tarinan kertomisessa paljon myös tämänkaltaista tekniikkaa - Lucin näkökulmasta kerrottua jaksoa lukuun ottamatta. Usein arvailut ja tulkinnat on esitetty suorien kysymysten muodossa. Ne haastavat myös lukijan miettimään, mikä niistä osuu lähimmäs totuutta:

Mietin itsekseni, miltä hänestä mahtoi tuntua autossaan. Oliko hän iloinen? Tunsiko hän ivallista riemua siitä että onnistui petkuttamaan lähimmäisiään niin täydellisesti? Olin varma ettei hän tuntenut. Oliko hän ahdistunut? [--] Itkikö hän otsa ohjauspyörää vasten painettuna? Vai eikö hän tuntenut yhtään mitään? (Valhe, 69.)

Arvailun ja päättelyn lisäksi kirjailija-kertoja korostaa monesti, että totuuden tapahtu- 
mista tietää vain Romand. Esimerkiksi kuvailtuaan juuri, mitä Romand mahdollisesti ajatteli tai tunsi, saattaa kirjailija-kertoja yhtäkkiä todeta, että vain Romand voisi kertoa totuuden tai ettei hänellä ole esittää asiasta edes arvausta.

Vaikka kirjailija-kertoja käyttääkin paljon edellä mainitun kaltaisia, Cohnin mukaan historiankirjoitukselle tyypillisiä kerronnan keinoja, ei Romandin tarinan kerronta ole kuitenkaan täysin ongelmatonta. Välillä - erityisesti, kun Romandin elämää ennen murhia seurataan pidempiä jaksoja kerrallaan - kerronta tuntuu hipovan vapaan epäsuoran esityksen rajoja ja kirjailija-kertoja painuu taka-alalle ulkopuolisen kolmannen persoonan kertojan tieltä. Mielenkiintoista kyllä, monet tämänkaltaiset kohdat tuntuvat liittyvän juuri Lucin näkökulmaan, aivan kuin kirjailija-kertoja kokisi Lucin tajunnan kuvauksen kauttaaltaan jollakin tavoin luontevammaksi teoksen loppupuolella tekemänsä "tunnustuksen" vuoksi. Kirjailija-kertoja ei kuitenkaan ole turhan tarkka muidenkaan henkilöhahmojen tajunnan kuvauksessa:

Hän [Luc] ei ollut koskaan arvostanut Corinnea, ja kaikki mitä hän oli naisesta kuullut oli vain vahvistanut hänen epäluuloaan. Mutta että Jean-Claude, juuri Jean-Claude! Että Jean-Claude petti Florencea! Sitä Luc ei olisi ikinä voinut ystävästään kuvitella. ${ }^{4}$ (Valhe, 85 .)

Paluumatkalla hän tutki yhä kalenteriaan kuin kiireinen liikemies. Joulu ei ollut hyvä ajankohta, se olisi lapsille liian julmaa. [--] Heti vuodenvaihteen jälkeenkö sitten? (Valhe, 103-104.)

Lisäksi Romandin tarina sisältää useita katkelmia, jotka kuvaavat jopa hyvin intiimejä tilanteita kirjailija-kertojan osoittamatta lainkaan, mistä tai keneltä kyseinen tieto on peräisin. Hyvä esimerkki on katkelma, joka kuvaa Romandin ja hänen vaimonsa Florencen kohtaamista sen jälkeen, kun Romand on jostakin käsittämättömästä syystä teeskennellyt joutuneensa auto-onnettomuuteen. Kyseinen kohta kuvaa tarkasti paitsi Romandin myös Florencen ajatuksia ja tunteita, eikä lukija voi olla miettimättä, miten kirjailija-kertoja voi tietää, mitä Romandin kuollut vaimo tuolloin tunsi. (Ks. Valhe, 86-87.)

Valheen kerronnan edellä mainitut piirteet tuovat monella tapaa mieleen Kylmäverisesti-teoksen kerrontatekniikan. Capote hyödyntää hiljaisuuden retoriikasta huolimatta teoksessaan myös ulkopuoliselle kolmannen persoonan kertojalle mahdollista kaikkitietävää asemaa astuessaan ajoittain henkilöhahmojen tajuntaan ja kuvatessaan heidän ajatuksiaan ja tunteitaan (ks. Anderson 1987, 53). Tämän vuoksi Capoten käyttämän kerrontatekniikan on usein nähty olevan ristiriidassa tekijän esittämän totuusväittämän kanssa. Vaikka Valheen kirjailija-kertoja ei esitäkään Capoten teokseen verrattavissa olevaa totuusväittämää, kiinnittävät edellä mainitun kaltaiset kerronnan keinot lukijan huomion kenties juuri siksi, että kysymys teoksen ei-fiktiivisyydestä tai fiktiivisyydestä jää alun alkaenkin avoimeksi. Henkilöhahmojen ajatusten ja 
tunteiden kuvaukseen liittyen Capoten ja Carrèren teoksia yhdistää myös kysymys siitä, miten tietämys henkilöiden sisäisestä maailmasta on hankittu. Valheen kirjailija-kertoja kuvaa Romandin elämän tapahtumia lapsuudesta murhiin saakka yksityiskohtaisesti, ja vaikka Romandin elämäntarina rakentuukin oikeudenistuntojen ympärille ja kerronnassa esiintyy paljon arvailua ja päättelyä, eivät ne täysin selitä sitä, mistä kirjailija-kertoja on tietonsa saanut. Myös Kylmäverisesti virittää pohtimaan, mihin tieto paitsi kuvatuista tapahtumista myös henkilöhahmojen ajatuksista ja tunteista pohjautuu. Kirjailija vakuuttaa teoksen alkulehdellä, että kaikki teoksen materiaali perustuu joko hänen omiin havaintoihinsa tai virallisiin asiakirjoihin, mutta itse teksti ei kuitenkaan viittaa kyseisiin lähteisiin tai erittele niitä. Tämänkaltaisen kerrontatekniikan voidaan tietysti Andersonin tavoin nähdä korostavan jokapäiväisen todellisuutemme arvoituksellisuutta ja sitä, että kirjailija voi todistusaineiston pohjalta esittää tapahtumista vain oman tulkintansa (Anderson 1987, 66-67). Sitä voidaan kuitenkin yhtälailla pitää tekstin fiktiivisyyteen viittaavana piirteenä (ks. Heyne 1987, 481-482; Lehtimäki 2005, 67) ja osasyynä siihen, miksi teos muistuttaa myös perinteistä realistista romaania.

Pohdittaessa kysymystä Valheessa käytettyjen kerrontatekniikoiden merkityksestä teoksen mahdolliselle ei-fiktiivisyydelle tai fiktiivisyydelle on henkilöhahmojen tajunnan kuvauksen ja ulkopuolisen kolmannen persoonan kerronnan lisäksi kiinnitettävä huomiota myös kerronnan rakenteeseen. Yhtäältä Valhe sisältää pitkiä jaksoja, joissa kerronta vaikuttaa lähes tai kokonaan ulkopuoliselta kolmannen persoonan kerronnalta, mutta toisaalta teoksessa on myös mittavia osuuksia, joissa tarina etenee lähes yksinomaan kirjailija-kertojan päättelyn, tulkinnan ja kommentoinnin varassa. Teoksen aloittavan, Lucin näkökulmasta esitetyn jakson jälkeen kerronta rakentuu ikään kuin kahden toisiinsa sekoittuvan tarinan varaan. Toinen niistä on kirjailija-kertojan kirjoittamisen prosessia reflektoiva tarina, joka alkaa päätöksestä kirjoittaa tapauksesta. Tarina kuvaa kirjailija-kertojan tiedon keräämistä, pyrkimystä tapauksen ymmärtämiseen sekä kirjoittamisen vaikeutta ja toistuvaa keskeytymistä. Tämä kirjoitusprosessia kuvaava tarina ja koko teos päättyy kirjailija-kertojan kuvaukseen siitä, kuinka hän viimein, vuosia tapauksen jälkeen, löysi oman rauhansa suhteessa siihen ja pystyi aloittamaan sen teoksen kirjoittamisen, jonka hän nyt päättää. Toinen tarinalinja kertoo Romandista alkaen miehen nuoruusvuosista ja päättyen murhenäytelmään ja valheiden paljastumiseen. Tämän tarinan kulku on rakennettu pitkälti Romandin oikeudenkäynnin ympärille, jota kirjailija-kertoja seurasi alusta loppuun kerätäkseen materiaalia työtään varten. Romandin elämäntarinan kertominen oikeusprosessin yhteydessä kietoo sen yhteen kirjailija-kertojan oman tarinan kanssa ja synnyttää samalla vaikutelman, että kirjailija-kertojan tiedot Romandin elämästä ovat peräisin pitkistä oikeudenistunnoista. Murhien jälkeen Romandin tarina saavuttaa kirjailija-kertojan tarinan, ja ne sulautuvat yhdeksi kokonaisuudeksi, jota kirjailija-kertojan näkökulma hallitsee. Kuten on jo 
todettu, kirjailija-kertojan tarina päättää teoksen.

Myös kerronnan rakenteen kohdalla Valheen vertaaminen Capoten Kylmäverisestiteokseen nostaa esiin mielenkiintoisia seikkoja. Monet tutkijat ovat kiinnittäneet huomiota Capoten teoksessaan käyttämään synkronisen kerronnan (synchronic narration) tekniikkaan, jonka avulla tekijä luo jännitteen Clutterin perheen viimeisen päivän ja heitä hitaasti lähestyvien murhaajien välille (ks. esim. Anderson 1987, 53-54; Zavarzadeh 1976, 117-118). Anderson huomauttaa, että Capote käyttää tekniikkaa myös viivyttäkseen tiettyjen tapausta koskevien asioiden paljastumista. Murhaajien saapuessa Clutterien talon pihaan siirtyy kerronta suoraan kuvaukseen ruumiiden löytymisestä, ja lukija saa odottaa varsinaisten murhien kuvausta teoksen loppupuolelle sijoittuvaan Perry Smithin tunnustukseen asti. (Anderson 1987, 53.) Valheen kerronnan rakenne muistuttaa tietyssä mielessä Capoten teoksen synkronista kerrontaa, vaikka Carrèren teos vuorotteleekin Romandin hitaasti murhia kohti ajautuvan elämäntarinan ja murhien jälkeisten tapahtumien (niin Romandin oikeudenkäynnin kuin teoksen kirjoitusprosessinkin) välillä. Romandin elämäntarina avautuu lukijalle synkronisesti sen paljastuessa vähitellen oikeudenkäynnin ja kirjailija-kertojan tutkimusten kautta. Kerronnan vuorottelun luoma jännite on pitkälti samankaltainen kuin Capoten teoksessa Valheen lukijan odottaessa kuvausta siitä, mitä todella tapahtui Romandin tappaessa perheensä. Samoin kuin Capote myös Carrère paljastaa lukijalle murhien seuraukset aloittamalla teoksen kuvauksella ruumiiden löytymisestä, mutta viivyttäen kuvausta varsinaisista tapahtumista teoksen loppupuolelle asti, jolloin myös teoksessa vuorottelevat tarinat sulautuvat yhteen.

Samoin kuin henkilöhahmojen sisäisen tajunnan kuvauksen ja ulkopuolisen kolmannen persoonan kerronnan kohdalla voidaan kysyä, onko tämänkaltaisella kerronnan rakenteella merkitystä teoksen ei-fiktiivisyydelle tai fiktiivisyydelle. Andersonin (1987, 53-54) ja Zavarzadehin (1976, 117-118) mukaan Capote on Kylmäverisestiteoksessaan valjastanut synkronisen kerronnan korostamaan teoksen faktuaalista voimaa, mutta teoksen metaforista rakennetta voidaan yhtä lailla pitää tietoisen romaanimaisena (eli yleensä tekstin fiktiivisyyteen viittavana) keinona, joka on ristiriidassa esitetyn totuusväittämän kanssa (Lehtimäki 2005, 67). Valhe ja Kylmäverisesti osoittavatkin havainnollisesti, että teoksen ei-fiktiivisyyden tai fiktiivisyyden märitteleminen kerronnan keinojen avulla - esimerkiksi Cohnin hahmotteleman mallin ${ }^{5}$ mukaan - on ongelmallista. Cohn ottaa kyllä huomioon, että tekstit kykenevät vastustamaan määrittämistään fiktioksi tai ei-fiktioksi antamalla ristiriitaisia viestejä siitä, kumpana ne olisi luettava, mutta katsoo kuitenkin, että tällaiset rajatapaukset itse asiassa vain tuovat fiktion ja ei-fiktion rajan selvemmin näkyviin ja tulevat kuitenkin lopulta luetuiksi jompanakumpana. (Cohn 2006, 40-41, 47-48, 76-78.) Ainakaan Valheen kohdalla tämä ei tunnu täysin pitävän paikkaansa. On totta, että teos kiinnittää huomion fiktion ja 
ei-fiktion väliseen rajaan juuri problematisoimalla sen, mutta teoksen kerronnan piirteet eivät tästä huolimatta tunnu ohjaavan selvästi fiktiiviseen tai ei-fiktiiviseen luentaan.

Lehman vastustaa ajatusta tekstin fiktiivisyyden tai ei-fiktiivisyyden märittelemisestä edellä mainitun kaltaisten kerronnan keinojen avulla. Hän toteaa esimerkiksi henkilöhahmojen ajatusten tai tapahtumien kuvauksen toimivan paitsi fiktiota ja ei-fiktiota erottavana tekijänä myös edustavan ei-fiktiivisten tekstien esityskeinojen haastavinta aluetta (Lehman 1997, 25). Lehmanin mukaan juuri se, etteivät nämä esityskeinot ole ei-fiktiossa viattomia, selittää ei-fiktiivisten tekstien voiman ja ongelmallisuuden. Lukijat voivat myöntää ei-fiktiolle oikeuden kyseisten esityskeinojen käyttöön, mutta tämä ei kuitenkaan tapahdu automaattisesti tai asiaa tutkimatta. Tämänkaltaiset esityskeinot, joita Lehman kutsuu James Phelanin tutkimukseen viitaten "mimeettisiksi lipsahduksiksi” (Phelan 1996, 106-110), eivät siis välttämättä muuta tekstiä fiktioksi, mutta tekevät näkyväksi kirjailijan työn ja sen takana olevan ideologian. (Lehman 1997, 35, 48-50.) Valheessa kirjailijan työ on eksplisiittisesti näkyvissä jo kirjailija-kertojan itsereflektiossa. Pohtimalla kerronnan mahdollisuuksia, sortumalla mimeettisiin lipsahduksiin ja samalla esittämällä, että aktuaalisilla tapahtumilla on merkitystä, teos tematisoituu kysymykseksi siitä itsestään ja koko ei-fiktiivisestä tekstilajista.

Vaikuttaisikin siltä, että kaunokirjallisessa ei-fiktiossa itserefleksiivisyys voi toimia myös edellä mainittujen mimeettisten lipsahdusten tai fiktiivisyyteen viittaavien kerronnan keinojen käytön oikeuttajana. Vaikka Capote ja Carrère käyttävät teoksissaan useita samankaltaisia kerrontatekniikkoja, olisi Valheen vaikea kuvitella joutuvan samankaltaisen kritiikin kohteeksi kuin Kylmäverisesti. Itsereflektion lisäksi asiaan vaikuttanee se, että Carrère ei Capoten tavoin väitä teoksen olevan täysin faktuaalinen. Myös Frus kiinnittää huomiota kysymykseen eksplisiittisen totuusväittämän merkityksestä verratessaan Capoten teosta Mailerin Pyövelin lauluun ja pitäessään yhtenä Mailerin teoksen vahvuuksista sitä, ettei se esitä olevansa absoluuttisen totuudenmukainen tai uskollinen faktoille. Frus vetää kuitenkin selkeän totuusväittämän puutteesta jokseenkin ongelmallisen johtopäätöksen, että Mailerin teos osoittaisi näin olevansa tietoinen omasta fiktiivisyydestään. (Frus 1994, 185.) Nähdäkseni eksplisiittisen totuusväittämän puuttumisesta on niin Pyövelin laulun kuin Valheen kohdalla pitkä matka teoksen kokonaisvaltaiseen fiktiivisyyteen. Sen, että teos kyseenalaistaa oman tekstilajinsa, ei tarvitse johtaa teoksen fiktiivisyyteen tai fiktion ja ei-fiktion välisen rajan katoamiseen. Pikemminkin voidaan ajatella, että juuri korostamalla ei-fiktion ongelmallisuutta Valheen ja Pyövelin laulun kaltaiset teokset itse asiassa korostavat eroaan fiktiosta.

\section{Rikos tai rukous}

Valheen kirjailija-kertoja toteaa viimeisinä sanoinaan ajatelleensa, että teoksen kirjoittaminen voisi olla vain joko rikos tai rukous. Toteamuksen koskettavuudesta huolimatta 
väittäisin, että kyse ei ole ensisijaisesti kummastakaan. Ajatus teoksen kirjoittamisesta rikoksena nostaa luonnollisesti esiin kysymykset ei-fiktion kirjoittamisen etiikasta ja tekijän mahdollisesti tuntemasta vastuusta, mutta Valhe ei ole sen enempää rikos kuin lukemattomat muutkaan todellisista rikoksista tuotetut tekstit. Voidaan myös väittää, että kirjailija-kertojan eksplisiittinen pyrkimys kantaa ottamansa vastuu lieventää mielikuvaa teoksesta edes moraalisena rikoksena. Ajatus teoksesta rukouksena puolestaan herättää kysymyksen siitä, kenen tai minkä puolesta rukoillaan. Romandin puolesta teosta on vaikea nähdä rukouksena, ja hänen tappamansa ihmisetkin jäävät nopeasti elävien varjoon. Ainoa selityskelpoinen mahdollisuus näyttäisikin olevan ajatus teoksesta rukouksena kirjailija-kertojan itsensä ja kenties sitä kautta laajemmin hänen oman todellisuuskäsityksensä puolesta. Rukouksena siitä, että kuvatun kaltaisille tapahtumille olisi lopulta olemassa jokin syy, selitys tai merkitys. Hayden White toteaa historian kerronnallistamisen olevan yritys saattaa historiallisen kokemuksen kaaos järjestyneeseen muotoon. Esimerkkinä edellisestä White käyttää kerronnan sulkeumaa (narrative closure) - lopetusta, joka antaa kerrotuille tapahtumille merkityksen erityisesti moraalisesta näkökulmasta. (White 1981, 20.) Samoin kuin Valhe ei ole selkeästi fiktio tai ei-fiktio, se ei ole myöskään yksinkertaisesti vain rikos tai rukous vaan pikemminkin Whiten kuvauksen kaltainen pyrkimys saattaa todelliset tapahtumat mielekkääseen muotoon. Edes teoksen itserefleksiivisyys ei peitä alleen kirjailija-kertojan tarvetta muodostaa tapahtumista merkityksellinen kokonaisuus - ei niinkään Romandia tai teoksen lukijaa vaan juuri itseään varten.

\section{Viitteet}

${ }^{1}$ Fiktion ja ei-fiktion kysymyksistä ks. mm. Cohn 2006, Doležel 1999, Ryan 1997 ja Walsh 2007. Ei-fiktio on käsitteenä ongelmallinen myös siksi, että se määrittyy negaation kautta, ja kuten Markku Lehtimäki toteaa, käsitettä käytetään usein myös merkityksessä ei-kaunokirjalliset tekstit (Lehtimäki 2005, 3n). Lehtimäki esittää kuitenkin itse, että eifiktion (nonfiction) käsite viittaa nykyisin ennen kaikkea ns. lajityypilliseen kirjoittamisen tapaan ("generic" mode of writing), joka luonnehtii erityisesti amerikkalaisia postmodernistisia tekstilajeja kuten uusjournalismia tai ei-fiktiivistä romaania (ibid., 3n ja 6n et passim). Lehtimäen tapa määritellä ei-fiktio on oman näkökulmani kannalta keskeinen, sillä asetan Carrèren Valheen vertailevan kirjallisuudentutkimuksen hengessä nimenomaan edellä mainitun kaltaisia tekstejä ja amerikkalaista tutkimustraditiota vasten. En kuitenkaan käytä ei-fiktion käsitettä vain tässä merkityksessä, vaan viittaan sillä tämän artikkelin puitteissa myös laajemmin kaikkiin niihin diskursseihin, jotka eivät ole fiktiota. Vaihtoehtoisista käsitteistä ks. mm. Genette 1991/1993, 55n; Doležel 1999, 267.

${ }^{2}$ Alkukielisessä tekstissä kyseisessä kohdassa esiintyy ranskan sana l’histoire ("ma place face à votre histoire"), joka tarkoittaa sekä historiaa (eli menneisyyttä) että tarinaa, kertomusta tai juttua ja viittaa näin osuvasti todellisten tapahtumien ja fiktiivisten kertomusten suhteen epämääräisyyteen.

${ }^{3}$ Vaikka itse vertailen Valhetta kahteen amerikkalaiseen, ei-fiktiivisiksi luettavaan 
teokseen, on vastaavia kysymyksiä ja Carrèren teosta toki tarkasteltu myös ranskalaisessa tutkimustraditiossa. Ks. esim. Le roman français au tournant du XXIe siècle (2004).

${ }^{4}$ Suomennos korvaa valitettavasti alkukielisessä tekstissä olevan kielikuvan katedraalin romahtamisesta ("C'était une cathédrale qui s'effondrait") lattealla toteamuksella ("Sitä Luc ei olisi ikinä voinut ystävästään kuvitella”) häivyttäen samalla vapaan epäsuoran esityksen tuntua. ${ }^{5}$ Cohnin mukaan tietyt tekstin piirteet ohjaavat lukemaan sitä fiktiona, ja hän erottaa kolme tekstin fiktiivisyyden osoittavaa tunnusmerkkiä, joista ensimmäinen on fiktiivisen tekstin riippuvuus perinteisestä tarina/kerronta-kahtiajaosta (story/discourse), kun taas ei-fiktiivisissä teksteissä tarinaa edeltää todellisten tapahtumien dokumentoitu taso (referenssi-tarinakerronta). (Cohn 2006, 132-134.) Kaksi muuta tekstin fiktiivisyyden tunnusmerkkiä ovat henkilöhahmojen sisäisen tietoisuuden kuvaus kolmannen persoonan kautta sekä kertovien äänten moninaistuminen ja erillisyys suhteessa teoksen aktuaaliseen tekijään. Kuvitteellisten hahmojen mielenliikkeitä on mahdollista kuvata tavoilla, jotka ovat ei-fiktiiviselle tekstille mahdottomia, ja lisäksi ei-fiktiivisen tekstin kertoja oletetaan aina identtiseksi tekstin aktuaalisen tekijän kanssa. (Ibid., 139-140, 146-147.)

\section{Lähteet}

Anderson, Chris i987: Style as Argument. Contemporary American Nonfiction. Carbondale: Southern Illinois University Press.

CARRÈre, EMMANUEL 2000: L'Adversaire. P.O.L. éditeur. CARrère, emmanuel 2000: Valhe. Käänt. Marja Haapio. Helsinki: Oy Like Kustannus. COHN, DORRIT 2006/I 999: Fiktion mieli. Käänt. Paula Korhonen, Markku Lehtimäki, Kai Mikkonen \& Sanna Palomäki. Helsinki: Gaudeamus.

DOLEŽEL, LUbOMír I999: Fictional and Historical Narrative. Meeting the Postmodernist Challenge. Teoksessa Narratologies. New Perspectives on Narrative Analysis. Ed. by David Herman. Columbus: Ohio State University Press, 247-273.

Frus, Phyllis I994: The Politics and Poetics of Journalistic Narrative. The Timely and the Timeless. Cambridge: Cambridge University Press.

GenetTe, Gérard 1993/1991: Fiction \& Diction. Käänt. Catherine Porter. Ithaca: Cornell University Press.

hellmann, JOHn I98I: Fables of Fact. The New Journalism as New Fiction. Urbana, Chicago \& London: University of Illinois Press.

HEYNE, ERIC 1987: Toward a Theory of Literary Nonfiction. Modern Fiction Studies 33:3, 479-490.

Lehman, DANIEL w. I997: Matters of Fact. Reading Nonfiction over the Edge. Columbus: Ohio State University Press.

LeHTIMÄKI, MARKKU 2005: The Poetics of Norman Mailer's Nonfiction. Self-Reflexivity, Literary Form, and the Rhetoric of Narrative. Tampere: Tampere University Press. phelan, James i 996: Narrative as Rhetoric. Technique, Audiences, Ethics, Ideology. Columbus: Ohio State University Press. 
Ryan, Marie-Laure i 997: Postmodernism and the Doctrine of Panfictionality. Narrative 5:2, 165-187.

WAlsh, RICHARD 2007: The Rhetoric of Fictionality. Narrative Theory and the Idea of Fiction. Columbus: The Ohio State University Press.

White, hayden i98 I: The Value of Narrativity in the Representation of Reality. Teoksessa On Narrative. Ed. by W.J.T. Mitchell. The University of Chicago Press. Chicago \& London, 1-23.

zavarzadeh, mas'ud i 976: The Mythopoeic Reality. The Postwar American Nonfiction Novel. Urbana, Chicago \& London: University of Illinois Press. 